\title{
Glycerol is not an inhibitor of mitochondrial citrate oxidation by Aspergillus niger
}

\author{
Inci Arisan-Atac† and Christian P. Kubicek \\ Author for correspondence: Christian P. Kubicek. Tel: +43158801 4707. Fax: +4315816266 \\ e-mail:ckubicek@fbch.tuwien.ac.at
}

Abteilung für Mikrobielle Biochemie, Institut für Biochemische Technologie und Mikrobiologie, TU

Wien, Getreidemarkt 9/1725, A-1060 Wien, Austria
We have re-assessed the hypothesis that an accumulation of intracellular glycerol triggers the accumulation of citric acid by Aspergillus niger by inhibiting the activity of the mitochondrial NADP-dependent isocitrate dehydrogenase isoenzyme. To this end, we have incubated mycelia of A. niger with $0.5 \mathrm{M}$ glycerol, which resulted in a maximal intracellular glycerol pool level of $0.92 \mathrm{M}$, comparable to that determined during the early phase of citrate accumulation. This addition affected neither the uptake of [1,5${ }^{14} \mathrm{C}$ ]citrate from the medium nor the rate of the subsequent release of ${ }^{14} \mathrm{CO}_{2}$ by the mycelia, indicating no effect on citrate oxidation. Mitochondria isolated from mycelia previously loaded with $0.5 \mathrm{M}$ glycerol contained $8 \%$ of the total mycelial glycerol. They released ${ }^{14} \mathrm{CO}$, from exogenously added $\left[1,5-{ }^{14} \mathrm{C}\right]$ citrate at the same rate as mitochondria isolated from mycelia not loaded with $0.5 \mathrm{M}$ glycerol. The addition of glycerol had no effect on the activity of the purified NADP-specific isocitrate dehydrogenase, but appeared to inhibit the activity in crude cell-free extracts of $A$. niger. We conclude that the intracellular accumulation of glycerol does not affect the rate of mitochondrial citrate oxidation and is therefore, in contrast to previous claims, not a trigger of citrate accumulation.

Keywords: Aspergillus niger, citric acid accumulation, glycerol, isocitrate dehydrogenase

\section{INTRODUCTION}

Selected strains of the filamentous fungus Aspergillus niger are capable of accumulating large amounts of citric acid from glucose, when cultivated under nutrient conditions favouring a high glycolytic flux rate, which has been the basis for the industrial production of citric acid for nearly 50 years (Kubicek \& Röhr, 1986; Röhr et al., 1992). The biochemical basis of this efficient metabolite overflow has been a matter of investigation for many years. Several authors have interpreted the accumulation of citric acid as being due to an inhibition of the enzymes of its further metabolism, e.g. aconitase and isocitrate dehydrogenase (for review see Kubicek \& Röhr, 1986), because the conversion of glucose to citric acid approaches almost quantitative yields (up to $90 \%$ ). While the possibility of such an inhibition occurring in vivo has been clearly disproved for aconitase (Kubicek \& Röhr, 1985), an inhibition of one of the enzymes catalysing isocitrate oxidation deserves re-appraisal.

† Permanent address: Institute of Biochemistry, Yildiz University, SisliIstanbul, Turkey.
Legisa and coworkers have published several papers in which they propose a major role for intracellular glycerol in the onset of citric acid accumulation by inhibiting the mitochondrial isoenzyme of the NADP-specific isocitrate dehydrogenase (Legisa \& Mattey, 1986; Legisa \& Kidric, 1989; Legisa et al., 1992; Legisa \& Gradisnik-Grapulin, 1995). They speculate that such an inhibition of isocitrate oxidation - because the NADP-linked enzyme accounts for more than $80 \%$ of the rate of mitochondrial citrate oxidation (Mattey, 1977; Jaklitsch et al., 1991) - causes (because of the aconitase equilibrium) accumulation of citrate, which also inhibits the NADP-specific isocitrate dehydrogenase (Mattey, 1977; Meixner-Monori et al., 1986), and therefore enhances citrate accumulation. The evidence for this model is essentially indirect, however, and its validity in vivo has never been tested critically.

In our laboratory, we routinely make use of $0.25 \mathrm{M}$ glycerol in buffers to stabilize labile enzymes during their purification, and did so also during our work on the NADP-specific isocitrate dehydrogenase (MeixnerMonori et al., 1986). During this work, we did not observe any effect of glycerol on the activity of the purified enzyme, which contrasts with the report of a $K_{\mathrm{i}}$ of 
$8 \mathrm{mM}$ of the enzyme for glycerol (Legisa \& Mattey, 1986). This finding prompted us to re-assess the validity of the glycerol theory of citric acid accumulation.

In the present paper, we show that a rise in intracellular glycerol has no effect on the catabolism of citrate in $A$. niger, either by whole mycelia or by isolated mitochondria. Furthermore we show that the inhibition of NADPspecific isocitrate dehydrogenase is obviously an artefact, since it is observed only with crude enzyme preparations. We therefore conclude that glycerol is not an initiator of citric acid accumulation.

\section{METHODS}

Materials. For citric acid production we used commercially available crystalline sucrose (food grade), which was purified by ion-exchange chromatography as described previously (Kubicek \& Röhr, 1977). All other chemicals used were standard analytical grade and provided by Merck.

Organism and culture conditions. The strain used in these experiments was Aspergillus niger ATCC 11414, a strain producing high yields of citric acid (Shu \& Johnson, 1948). In selected experiments, $A$. niger strains B-60 (IMI 309 921) and N400 (CBS 120.49) were also used. Methods for cultivation under non-citric-acid-producing conditions, and the maintenance and preparation of conidia for inoculation, have been described previously (Ma et al., 1981). To produce citric acid, the strain was grown in the medium of Shu and Johnson as described previously (Kubicek \& Röhr, 1977).

Enzyme assays. NADP-specific isocitrate dehydrogenase was assayed as described by Meixner-Monori et al. (1986). Marker enzymes for subcellular fractions were assayed as described by Lendenfeld et al. (1993). Succinate dehydrogenase (EC 1.3.99.1) was assayed by the spectrophotometric method described by Veeger $e t$ al. (1969). Enzyme activities are given as units $\mathrm{ml}^{-1}$. One unit is defined as the amount of enzyme catalysing the formation of $1 \mu \mathrm{mol}$ product $\mathrm{min}^{-1}$ at a linear rate under the conditions given. Specific activities are given as $\mathrm{U}$ (mg protein $)^{-1}$. Protein concentrations were determined by the dye-binding procedure (Bradford, 1976).

Purification of NADP-specific isocitrate dehydrogenase. The enzyme was purified from mycelia grown for $36 \mathrm{~h}$ on $1 \%(\mathrm{w} / \mathrm{v})$ glucose as carbon source as described previously (MeixnerMonori et al., 1986).

Uptake of citric acid and citric acid oxidation by mycelia. To study the oxidation of $\left[1,5^{-14} \mathrm{C}\right]$ citric acid by mycelia of $A$. niger, they were pregrown on $1 \%(\mathrm{w} / \mathrm{v})$ glucose for $28 \mathrm{~h}$ (at which time they were approximately in the middle of their growth phase). The mycelium from one flask was harvested on a Buchner funnel (G1 porosity) without suction, and washed three times with a total of $200 \mathrm{ml}$ of fresh nutrient medium. It was then suspended in fresh nutrient medium to give a mycelial suspension of approximately $2 \mathrm{~g} \mathrm{dry} \mathrm{wt} \mathrm{l}^{-1}$, and divided into two parts. One part was mixed with an equal volume of fresh nutrient medium, whereas the other part was mixed with an equal volume of fresh nutrient medium which also contained $1 \mathrm{M}$ glycerol. Portions $(10 \mathrm{ml})$ of both suspensions were distributed into several $100 \mathrm{ml}$ Erlenmeyer flasks and pulsed with $0.37 \mathrm{MBq}\left[1,5^{-14} \mathrm{C}\right]$ citric acid $\left(4 \cdot 1 \mathrm{GBq} \mathrm{mmol}^{-1}\right.$; Amersham). Each Erlenmeyer flask was sealed with a rubber stopper and connected, via a Teflon tube and a glass pipe ( $5 \mathrm{~mm}$ diam.), to a sealed $50 \mathrm{ml}$ washing flask containing $5 \mathrm{ml} 1 \mathrm{M} \mathrm{Na}_{2} \mathrm{CO}_{3}$. ${ }^{14} \mathrm{CO}_{2}$ trapped in the $\mathrm{Na}_{2} \mathrm{CO}_{3}$ solution was determined for a period of $4 \mathrm{~h}$ by pipetting $0.5 \mathrm{ml}$ samples into $10 \mathrm{ml}$ LSCcocktail (Pharmacia-LKB) and measuring their radioactivity by liquid scintillation counting. The radioactivity was related to the amount of mycelial biomass, which was determined from separate samples of the original mycelial suspension.

In order to measure the uptake of $\left[1,5-{ }^{14} \mathrm{C}\right]$ citrate, mycelial suspensions were prepared and $10 \mathrm{ml}$ portions were distributed into $100 \mathrm{ml}$ Erlenmeyer flasks as described above. After pulsing with citrate, $0.5 \mathrm{ml}$ samples of the broth were withdrawn and mixed with $1 \mathrm{ml}$ ice-cold $1 \mathrm{M}$ sodium citrate $(\mathrm{pH} \mathrm{5.0)}$. The mycelia were then harvested by filtration through GF/C glassfibre filters (Whatman) and the radioactivity was measured in a liquid scintillation system.

Cell fractionation. Damp mycelium $(5 \mathrm{~g})$ was washed with tap water, blotted dry between filter paper, suspended in $35 \mathrm{ml}$ $10 \mathrm{mM}$ Tris/ $\mathrm{HCl}$ buffer, pH 7.5 (containing $2 \mathrm{mM}$ EDTA, $50 \mathrm{mM}$ dithiothreitol, $2 \mathrm{mM}$ PMSF, $3 \mathrm{mM} \mathrm{MgCl}_{2}$, and $1 \mathrm{M}$ sorbitol), and mixed with $30 \mathrm{~g}$ glass beads $(0.45-0.50 \mathrm{~mm}$ diam.; Braun) in a $75 \mathrm{ml}$ beaker. The beaker was then placed into a Bead-Beater homogenizor, cooled by ice, and homogenized by eight 30 -s treatments, interrupted by 3 min coolingperiods. The homogenate was withdrawn, the sedimented glass beads removed, and the cellular debris and nuclei centrifuged at $1000 \mathrm{~g}\left(4^{\circ} \mathrm{C}, 10 \mathrm{~min}\right)$. Portions $(8 \mathrm{ml})$ of the supernatant were then placed on $32 \mathrm{ml}$ of a $0 \cdot 33-2 \mathrm{M}$ sucrose gradient and centrifuged at $80000 \mathrm{~g}$ for $2 \mathrm{~h}$ at $4{ }^{\circ} \mathrm{C}$ in a swing-out rotor. Fractions of $2 \mathrm{ml}$ were then isolated from the top and assayed for protein, glycerol, and activity of marker enzymes (glucose6-phosphate dehydrogenase, EC 1.1.1.49; $\alpha$-mannosidase, EC 3.2.1.24; acid phosphatase, EC 3.1.3.2; citrate synthase, EC 4.1.3.7; succinate dehydrogenase). Fractions with high citrate synthase and succinate dehydrogenase activities only were again pelleted by centrifugation (see above), suspended in extraction buffer, and used as the source of mitochondria for further experiments.

Uptake of citric acid and citric acid oxidation by mitochondria. Portions $(1 \mathrm{ml})$ of mitochondria, suspended in isotonic buffer $(10 \mathrm{mM}$ Tris/ $\mathrm{HCl}$ buffer, $\mathrm{pH} 7.5$; containing $2 \mathrm{mM}$ EDTA, $50 \mathrm{mM}$ dithiothreitol, $3 \mathrm{mM} \mathrm{MgCl}_{2}$, and $1 \mathrm{M}$ sorbitol), were pipetted into $5 \mathrm{ml}$ vials $(3 \times 1.3 \mathrm{~cm}$ diam.), each of which was connected via a $1 \mathrm{~mm}$ Teflon tube to a second vial containing $0.5 \mathrm{ml} 1 \mathrm{M} \mathrm{Na}_{2} \mathrm{CO}_{3}$, into which the tube tip was immersed. The mitochondrial suspensions were gently agitated by a $1 \mathrm{~cm}$ stirring bar. After pulsing with $\left[1,5-{ }^{14} \mathrm{C}\right]$ citric acid, $50 \mu$ samples from the $1 \mathrm{M} \mathrm{Na}_{2} \mathrm{CO}_{3}$ solution were withdrawn for a period of up to $6 \mathrm{~h}$, added to $4 \mathrm{ml}$ LSC-cocktail (PharmaciaLKB) and the radioactivity measured. Radioactivity released was related to the amount of mitochondrial protein, which was assayed by mixing equal volumes of the mitochondrial suspension and $1 \mathrm{M} \mathrm{NaOH}$, vortexing for $1 \mathrm{~min}$, removing insoluble contents by centrifugation (Eppendorf centrifuge, $10 \mathrm{~min}$ ), and assaying the protein concentration of the supernatant by the method of Bradford (1976).

Oxidation of citrate by mitochondria. This was done as described by Watson \& Smith (1967), using a Clark electrode (Oxygen Analyzer, Yellow Springs).

Analysis of biomass and citric acid formation. This was done as described by Röhr et al. (1981). Citric acid and glycerol in the culture fluid were determined by HPLC, using an Aminex HPX-87N column $(300 \times 7.8 \mathrm{~mm}$; Biorad $)$ equipped with a Carbo $\mathrm{C}$ precolumn, using water (HPLC-grade, Merck) at $65^{\circ} \mathrm{C}$ as the eluent. During cell fractionation experiments, glycerol was determined by enzymic analysis (Eggstein \& Kuhlmann, 1974) using a commercial test kit (Boehringer-Mannheim). 


\section{RESULTS}

Manipulation of intracellular glycerol in Aspergillus niger by addition of extracellular glycerol

Our rationale for investigating the in vivo validity of the ' glycerol hypothesis' was to modulate the mitochondrial glycerol pool in $A$. niger and to study the resulting effect on citrate oxidation. As a prerequisite for this approach, appropriate conditions for modulation had to be established first. To this end, we added various concentrations of extracellular glycerol to young mycelia and studied the resulting total intracellular glycerol concentration during further incubation. Table 1 shows that the incubation of mycelia in $0.5 \mathrm{M}$ glycerol for $4 \mathrm{~h}$ resulted in a rise of the total intracellular glycerol concentration up to $0.94 \mathrm{M}$, which compares well with glycerol concentrations observed during citric acid accumulation (Legisa $\&$ Mattey, 1986). In order to assess whether this increased glycerol pool also occurs in the mitochondria, mycelia from incubations in $0.5 \mathrm{M}$ glycerol were subjected to subcellular fractionation, and the glycerol concentration of individual fractions was analysed (Fig. 1c). Most of the glycerol was found in a very light fraction, which also contained glucose-6-phosphate dehydrogenase activity, and which was therefore tentatively identified as the cytoplasmic fraction. However, two other fractions, one enriched with hydrolytic enzyme activities and the other with citrate synthase and succinate dehydrogenase, also contained detectable glycerol. When the total amounts of glycerol found in individual fractions were combined and compared, the cytoplasm was shown to contain $76 \%$, and the mitochondrial fraction $17 \%$ of total cellular glycerol, respectively. Control mycelia (those which had not been incubated in glycerol), although containing less glycerol, contained an even higher proportion of total glycerol in the cytoplasmic fraction $(84 \%)$, whereas the proportion in the two other fractions was low. The specific glycerol content of the combined putative mitochondrial peak fractions (fractions 19-24) was 3.7 and $0.64 \mu \mathrm{mol}$ (mg protein $)^{-1}$ for glycerol-loaded and non-loaded mycelia, respectively. Assuming an intracellular volume of the mitochondria of $0 \cdot 8-1 \cdot 8 \mu \mathrm{l}(\mathrm{mg} \text { protein) })^{-1}$ (Srere, 1980), the glycerol concentrations would be between 2 and $4 \mathrm{M}$

Table 1. Effect of addition of extracellular glycerol on the intracellular glycerol pool in A. niger

\begin{tabular}{|ccc|}
\hline $\begin{array}{c}\text { Added glycerol } \\
(\mathbf{M})\end{array}$ & \multicolumn{2}{c|}{ Intracellular glycerol $(\mathbf{M})^{*}$} \\
\cline { 2 - 3 } & 2 h incubation & $\mathbf{4} \mathbf{h}$ incubation \\
\hline 0 & $0 \cdot 32 \pm 0 \cdot 05$ & $0 \cdot 30 \pm 0 \cdot 05$ \\
$0 \cdot 1$ & $0 \cdot 36 \pm 0 \cdot 05$ & $0 \cdot 40 \pm 0 \cdot 07$ \\
$0 \cdot 2$ & $0 \cdot 42 \pm 0 \cdot 08$ & $0 \cdot 54 \pm 0 \cdot 08$ \\
$0 \cdot 3$ & $0 \cdot 47 \pm 0 \cdot 08$ & $0 \cdot 61 \pm 0 \cdot 10$ \\
$0 \cdot 4$ & $0 \cdot 48 \pm 0 \cdot 08$ & $0 \cdot 83 \pm 0 \cdot 12$ \\
$0 \cdot 5$ & $0 \cdot 54 \pm 0 \cdot 56$ & $0 \cdot 94 \pm 0 \cdot 16$ \\
\hline
\end{tabular}

* Mean intracellular concentration in whole cells $( \pm \mathrm{sD}, n=3)$, using a value for intracellular volume of $2 \cdot 4 \mathrm{ml}$ (g dry weight $)^{-1}$.
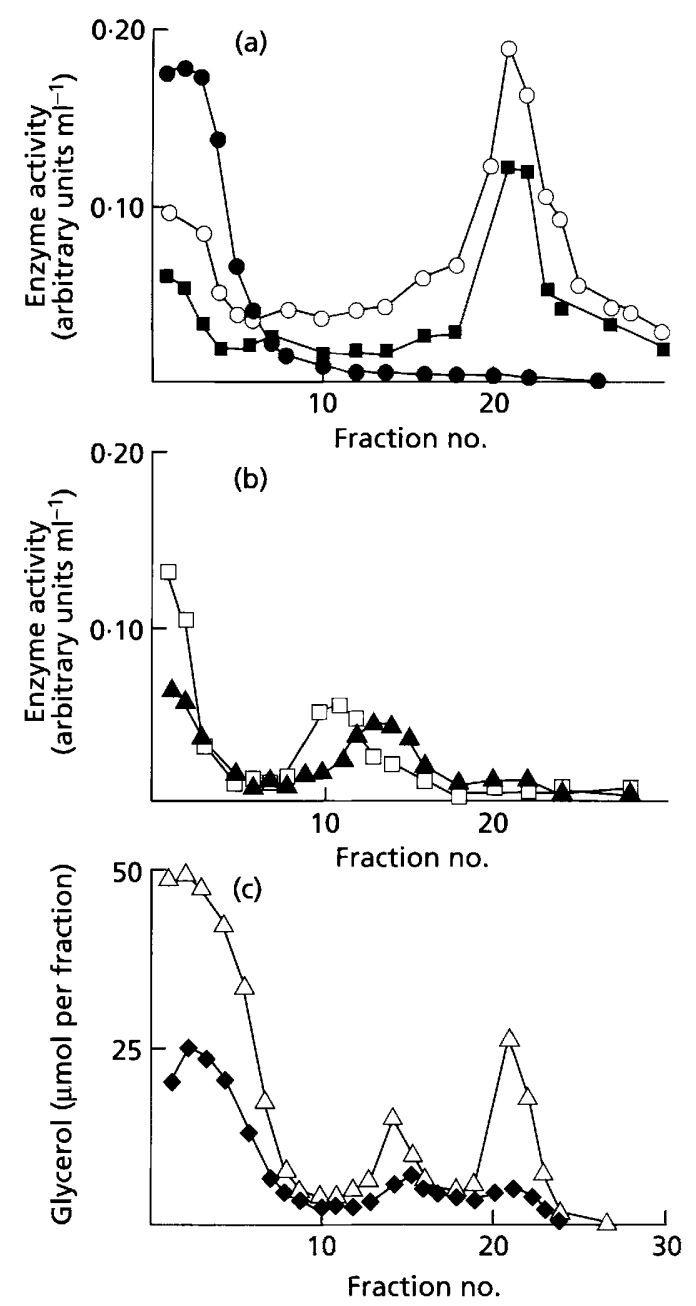

Fig. 1. Subcellular fractionation of $A$. niger. Fractions $(2 \mathrm{ml})$ were collected from a sucrose gradient, starting at the top of the tube, and were assayed for (a) glucose-6-phosphate dehydrogenase (O), citrate synthase (O), succinate dehydrogenase $(\boldsymbol{C})$; (b) $\alpha$-mannosidase $(\boldsymbol{A})$, acid phosphatase $(\square)$; (c) glycerol: $(\triangle)$, mycelia incubated in $0.5 \mathrm{M}$ glycerol; ( $\bullet$ ) mycelia without preincubation in glycerol. Enzyme activities are given in arbitrary units in order to fit them into the same graph. Values are from a single experiment, but consistent data were obtained in two other experiments.

for glycerol-loaded cells and between 0.3 and $0.8 \mathrm{M}$ for control cells. This indicates that mycelia not pre-loaded with glycerol already contain a mitochondrial glycerol concentration which is in excess of the $K_{\mathrm{i}}$ reported for inhibition of mitochondrial NADP-specific isocitrate dehydrogenase. Both concentrations should be sufficient to inhibit mitochondrial citrate oxidation.

\section{Oxidation and accumulation of citrate by glycerol- loaded mycelia of $A$. niger}

Having established that the addition of $0.5 \mathrm{M}$ glycerol dramatically enhances the mitochondrial pool of glycerol in $A$. niger, we then examined its effect on the oxidation of citrate in vivo. For this purpose, we incubated the mycelia 

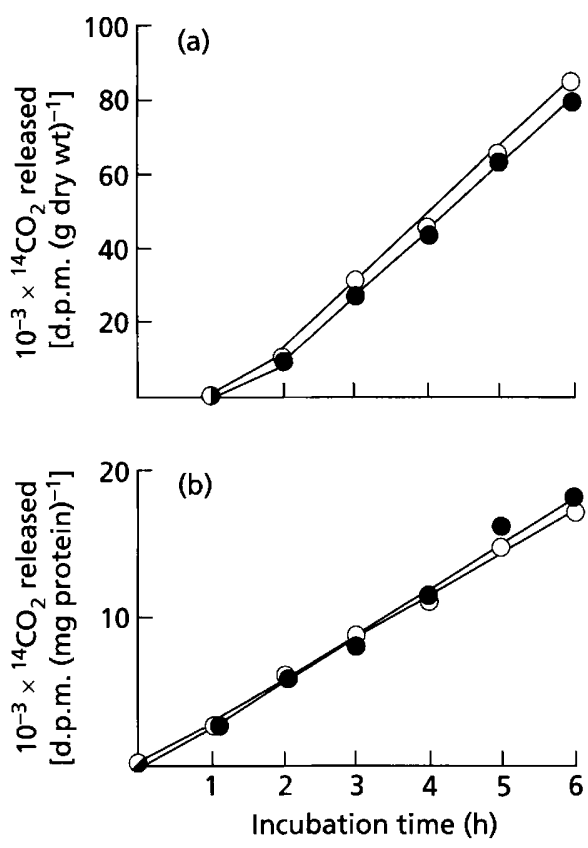

Fig. 2. Release of ${ }^{14} \mathrm{CO}_{2}$ from $\left[1,5-{ }^{14} \mathrm{C}\right]$ citrate by mycelia (a) and mitochondria (b) of $A$. niger, preincubated $(O)$ or not preincubated (O) in glycerol. Values are from a single experiment, but consistent data were obtained in five other experiments. The calculated rates varied by less than $10 \%$.

in $0.5 \mathrm{M}$ glycerol, and then added $\left[1,5-{ }^{14} \mathrm{C}\right]$ citrate and analysed the release of ${ }^{14} \mathrm{CO}_{2}$. Because of the labelling at the $\mathrm{C}$-atoms 1 and 5 , release of ${ }^{14} \mathrm{CO}_{2}$ can only result from mitochondrial oxidation. Preliminary experiments showed that more than $97 \%$ of the exogenously added labelled citrate had been taken up within $90 \mathrm{~min}$ of incubation. After a lag-time of about $45 \mathrm{~min}$ the mycelia started to release ${ }^{14} \mathrm{CO}_{2}$ at a linear rate. No differences could be detected in the rates of ${ }^{14} \mathrm{CO}_{2}$ release between mycelia preincubated or not preincubated with glycerol, suggesting that the catabolism of citrate was not affected (Fig. 2a). Also, the total intracellular citrate concentration did not significantly change during this experiment and remained at $1 \cdot 3 \pm 0 \cdot 4 \mathrm{mM}$.

\section{Metabolism and accumulation of citrate by glycerol- loaded mitochondria of $A$. niger}

In order to support the results obtained with whole, intact mycelia, similar experiments were carried out with isolated mitochondria. For this purpose, we isolated the mitochondria from mycelia preincubated in $0.5 \mathrm{M}$ glycerol and also from control mycelia. Although our procedure did not result in the preparation of coupled mitochondria, they took up citrate and oxidized it, and were thus considered suitable for this study. Fig. 2(b) shows that both types of mitochondria release ${ }^{14} \mathrm{CO}_{2}$ at comparable rates, and are thus not affected in their citrate oxidizing capacity by the glycerol content. Similar findings were obtained when the respiratory activity of the mitochondria with citrate and succinate was compared
Table 2. Effect of glycerol addition on the activity of NADP-specific isocitrate dehydrogenase from $A$. niger

One unit (U) of enzyme activity is the amount of enzyme catalysing the formation of $1 \mu \mathrm{mol}$ product $\mathrm{min}^{-1}$. Activities were assayed in triplicate and the values are given as means $\pm \mathrm{sD}$.

\begin{tabular}{|c|c|c|c|}
\hline \multirow{2}{*}{$\begin{array}{c}\text { Glycerol } \\
\text { concn } \\
(\mathrm{mM})\end{array}$} & \multicolumn{3}{|c|}{ Enzyme activity $\left(\mathrm{U} \mathrm{ml}^{-1}\right)$} \\
\hline & $\begin{array}{l}\text { Cell-free } \\
\text { extracts }\end{array}$ & $\begin{array}{l}\text { Purified } \\
\text { enzyme }\end{array}$ & $\begin{array}{c}\text { Mixture of } \\
\text { both* }\end{array}$ \\
\hline 0 & $1 \cdot 24 \pm 0 \cdot 13$ & $0.44 \pm 0.07$ & $0 \cdot 82 \pm 0 \cdot 10$ \\
\hline $5 \cdot 9$ & $1 \cdot 24 \pm 0 \cdot 15$ & $0 \cdot 48 \pm 0 \cdot 10$ & $0 \cdot 80 \pm 0 \cdot 13$ \\
\hline $11 \cdot 9$ & $1 \cdot 12 \pm 0 \cdot 13$ & $0.44 \pm 0.08$ & $0 \cdot 75 \pm 0 \cdot 11$ \\
\hline $17 \cdot 8$ & $1 \cdot 03 \pm 0.10$ & $0.42 \pm 0.06$ & $0.72 \pm 0.09$ \\
\hline $33 \cdot 4$ & $0.87 \pm 0.08$ & $0 \cdot 44 \pm 0.06$ & $0.57 \pm 0.06$ \\
\hline $59 \cdot 0$ & $0.78 \pm 0.08$ & $0.46 \pm 0.07$ & $0.51 \pm 0.05$ \\
\hline
\end{tabular}

* Cell free extract $(0.8 \mathrm{U})$ and the purified enzyme $0.8 \mathrm{U}$ were mixed in a total volume of $3.0 \mathrm{ml}$.

[7.8 and $7.6 \mu \mathrm{mol}$ oxygen consumed $\min ^{-1}(\mathrm{mg} \text { protein })^{-1}$ by mitochondria from mycelia preincubated without and with $0.5 \mathrm{M}$ glycerol, respectively], and this finding was not influenced by substituting $1 \mathrm{M}$ glycerol for $1 \mathrm{M}$ sorbitol in the buffer used for the incubation of mitochondria (data not shown). The latter was done to ensure that glycerol did not leak out of the mitochondria during incubation. From these data we conclude that glycerol has no effect on the mitochondrial oxidation of citrate in $A$. niger.

\section{Effect of glycerol on NADP-specific isocitrate dehydrogenase from $A$. niger}

In view of our findings that glycerol does not affect the mitochondrial oxidation of citrate, we wanted to find out whether the mitochondrial NADP-specific isocitrate dehydrogenase of $A$. niger is affected by glycerol. To this end we purified the enzyme to physical homogeneity and investigated its activity in the presence of various concentrations of glycerol (Table 2). With an actual Mgisocitrate concentration of $0.1 \mathrm{mM}$, which is about the $K_{\mathrm{m}}$ of the enzyme, no inhibition could be observed even at concentrations of $59 \mathrm{mM}$, which represent a 7.5-fold excess over the $K_{\mathbf{i}}$ values reported by Legisa \& Mattey (1986), and should therefore have resulted in an inhibition of at least $85 \%$. In order to rule out that this effect was dependent on the strain used, we also purified and investigated the enzyme from the other $A$. niger strains, B60 (high-citric acid producer; Röhr et al., 1979) and N-400 (a moderate citric acid producer; unpublished data). Essentially similar results were obtained with both these strains.

Interestingly, glycerol appeared to inhibit the activity of NADP-specific isocitrate dehydrogenase in cell-free extracts (Table 2). Since the mitochondrial and the cytoplasmic isoenzymes of $A$. niger are identical (Meixner- 
Monori et al., 1986; Jaklitsch et al., 1991), we suspected that this may be due to an artefact. To test this, we added the purified mitochondrial NADP-specific isocitrate dehydrogenase to cell-free extracts, and examined the inhibition of the resulting total activity by glycerol (Table 2 ). We found that the activity of the purified enzyme was also inhibited by glycerol when mixed with the crude cellfree extract. Controls, using cell-free extracts that had been heated for $10 \mathrm{~min}$ in a boiling water bath did not show this effect, whereas the effect was maintained during dialysis. We therefore conclude that this inhibition was caused by a protein present in the cell-free extracts, which either inhibited or inactivated NADP-specific isocitrate dehydrogenase activity.

\section{DISCUSSION}

The data presented in this paper show that a significant rise in the intracellular pool of glycerol has no effect on the oxidation of $\left[1,5-{ }^{14} \mathrm{C}\right]$ citrate within the citric acid cycle, hence disproving earlier theories (Legisa \& Mattey, 1986; Legisa et al., 1992) that glycerol may inhibit the mitochondrial NADP-specific isocitrate dehydrogenase. It should be noted that because of the labelling of citrate in positions 1 and 5 , our approach quantified the $\mathrm{CO}_{2}$ released during the 2-oxoglutarate dehydrogenase reaction ( $1 \mathrm{~mol} \mathrm{CO}_{2}$ per cycle) and not release by isocitrate dehydrogenation itself. This seems to be legitimate, however, since citrate has to pass the isocitrate dehydrogenation step for this purpose and, since the rates observed were similar, isocitrate dehydrogenation is either not limiting the flux through the cycle or, if limiting, is displaying the same activity irrespective of the presence of glycerol. Both possibilities strongly argue against an inhibition of citrate oxidation by glycerol. It should also be noted that other metabolic reactions are unlikely to affect the method used here: in theory, $[1,5$ ${ }^{14} \mathrm{C}$ ]citrate may be cleaved by ATP-citrate lyase and used for lipid biosynthesis. Such a process would conserve the radioactive label in fatty acids, and subsequently release $\mathrm{CO}_{2}$. We consider it unlikely that such a pathway would have interfered with our approach, since the rates of ${ }^{14} \mathrm{CO}_{2}$ evolution during the $6 \mathrm{~h}$ of the experiment were, after an initial lag, essentially linear, and less than $10 \%$ of the level of radioactivity measured in $\mathrm{CO}_{2}$ was found in a chloroform/methanol extract of $A$. niger mycelium harvested at the end of the experiment (data not shown).

Consistent with the lack of effect on citrate oxidation in vivo, glycerol had also, in contrast to previous reports (Legisa \& Mattey, 1986), no effect on the purified enzyme. Legisa et al. (1992) interpreted the inhibitory effect of glycerol in terms of structural similarities between citrate (which is a competitive inhibitor of the NADP-specific isocitrate dehydrogenase; Mattey, 1977; Meixner-Monori et al., 1986) and glycerol (Legisa et al., 1992). However, the inhibition by citrate is related to its ability to compete for the divalent metal ion required to chelate isocitrate (Meixner-Monori et al., 1986), an effect which cannot be achieved by glycerol due to the absence of carboxylic groups in the glycerol molecule. Moreover, binding of the substrate to the active centre of the NADP-specific isocitrate dehydrogenase requires both a chelated carboxylic group as well as a hydroxylic group (Ehrlich \& Colman, 1987). All these data are consistent with our findings that glycerol does not inhibit this enzyme.

While the present data disprove the theory that glycerol inhibits mitochondrial citrate oxidation, they do not offer any other explanation for the triggering of citric acid accumulation. However, it should be pointed out here that, based on available data, there is no need to postulate an inhibition of citrate breakdown at either aconitase or one of the two isocitrate dehydrogenases. This is clearly illustrated by the following calculation. During the early phase of citric acid accumulation $(20-45 \mathrm{~h}$ of fermentation), the biomass concentration of $A$. niger rises from $0 \cdot 2$ to $1.4 \mathrm{~g} \mathrm{l}^{-1}$ (Röhr \& Kubicek, 1981). During the latter half of this period, the total citric acid concentration (i.e. intra- plus extracellular) rises from 0.08 to $1.8 \mathrm{mM}$ (Kubicek \& Röhr, 1981). Using published data for the protein and amino-acid composition of $A$. niger biomass during this phase (Kubicek et al., 1979), the minimal metabolic flux from glucose to 2-oxoglutarate can be calculated as $1.4 \mu \mathrm{mol} 2$-oxoglutarate formed $\mathrm{min}^{-1}$ (g biomass dry wt) ${ }^{-1}$ (Zehentgruber, 1980 ; cited in Röhr \& Kubicek, 1981). This value accounts for $73 \%$ of the total activities of both the NADP- and NAD-specific isocitrate dehydrogenases $\left.[1.9 \mathrm{U} \text { (g biomass dry } \mathrm{wt})^{-1}\right]$ measured in vitro. Comparable flux rates are also obtained for fermentations with strains producing low levels of citric acid or with high-yielding strains under conditions of impaired citrate accumulation (i.e. in the presence of manganese ions). Given the fact that the in vivo concentration of the $\mathrm{Mg}$-isocitrate complex is between 0.12 and $0.22 \mathrm{mM}$ during this period (Kubicek \& Röhr, 1985), and considering that the NAD-specific isocitrate dehydrogenase (which accounts for only about $15 \%$ of total isocitrate dehydrogenase activity in vitro; Jaklitsch et al., 1991) has a substrate affinity similar to that of the NADP-specific enzyme ( $K_{\mathrm{m}} 0.08 \mathrm{mM}$; Meixner-Monori et al., 1986), the observed in vivo flux matches perfectly that which can be predicted from the in vitro data. All this is consistent with our hypothesis (cf. Röhr et al., 1992; Kubicek et al., 1993) that citric acid accumulation is initiated because of substrate overflow and not because of a limitation of its catabolism.

\section{ACKNOWLEDGEMENTS}

This work was supported by a grant to I. A.-A. from Section Microbial Biochemistry, IBTM, TU Wien. The authors are grateful to D. Kristufek, M. F. Wolschek and A. Netik of the senior author's Institute for their help in the course of this study.

\section{REFERENCES}

Bradford, M. M. (1976). A rapid and sensitive method for the quantitation of microgram quantities of protein utilizing the principle of protein-dye binding. Anal Biochem 72, 248-254.

Eggstein, M. \& Kuhlmann, E. (1974). Triglycerides and glycerol determinations after alkaline hydrolysis. In Methods of Enzymatic Analysis, 2nd edn. vol. 4, pp. 1825-1831. Edited by H. U. Bergemeyer. Weinheim: Verlag Chemie. 
Ehrlich, R. S. \& Colman, R. F. (1987). Ionization of isocitrate bound to pig heart $\mathrm{NADP}^{+}$-dependent isocitrate dehydrogenase: ${ }^{13} \mathrm{C}$ NMR study of substrate binding. Biochemistry 26, 3461-3466.

Jaklitsch, W. M., Kubicek, C. P. \& Scrutton, M. C. (1991). Intracellular location of enzymes involved in citrate production by Aspergillus niger. Can J Microbiol 37, 823-827.

Kubicek, C. P. \& Röhr, M. (1977). Influence of manganese on enzyme sythesis and citric acid accumulation in Aspergillus niger. Eur J Appl Microbiol 4, 167-173.

Kubicek, C. P. \& Röhr, M. (1981). Regulatory aspects of citric acid fermentation by Aspergillus niger. Proc Biochem 16, 34-37.

Kubicek, C.P. \& Röhr, M. (1985). Aconitase and citric acid fermentation by Aspergillus niger. Appl Environ Microbiol 50, 1336-1338.

Kubicek, C. P. \& Röhr, M. (1986). Citric acid fermentation. CRC Crit Rev Biotechnol 3, 331-367.

Kubicek, C. P., Hampel, W. A. \& Röhr, M. (1979). Manganese deficiency leads to elevated amino acid pools in citric acid accumulating Aspergillus niger. Arch Microbiol 123, 73-79.

Kubicek, C. P., Witteveen, C. F. B. \& Visser, J. (1993). Regulation of organic acid production by Aspergilli. In: The Genus Aspergillus. From Taxonomy and Genetics to Industrial Application. FEMS Symposium no. 69. pp. 135-145. Edited by K. A. Powell, A. Renwick \& J.F. Peberdy. New York and London: Plenum Press.

Legisa, M. \& Gradisnik-Grapulin, M. (1995). Sudden substrate dilution induces a higher rate of citric acid production in Aspergillus niger. Appl Environ Microbiol 61, 2732-2737.

Legisa, M. \& Kidric, J. (1989). Initiation of citric acid accumulation in the early stages of Aspergillus niger growth. Appl Microbiol Biotechnol 31, 453-457.

Legisa, M. \& Mattey, M. (1986). Glycerol as an initiator of citric acid accumulation in Aspergillus niger. Envyme Microb Tecbnol 8 , 258-259.

Legisa, M., Jernejc, K. \& Cimerman, A. (1992). New aspects of citric acid accumulation in Aspergillus niger. Biopractice 1, 44- 48.

Lendenfeld, T., Ghali, D., Wolschek, M., Kubicek-Pranz, E. M. \& Kubicek, C. P. (1993). Subcellular compartmentation of penicillin biosynthesis in Penicillium cbrysogenum. The amino acid precursors are derived from the vacuole. $J$ Biol Chem 268, 665-671.

Ma, H., Kubicek, C. P. \& Röhr, M. (1981). Malate dehydrogenase isoenzymes in Aspergillus niger. FEMS Microbiol Lett 12, 147-151.

Mattey, M. (1977). Citrate regulation of citric acid production by Aspergillus niger. FEMS Microbiol Lett 2, 71-74.

Meixner-Monori, B., Kubicek, C. P., Schreferl-Kunar, G., Harrer, W. \& Röhr, M. (1986). NADP-specific isocitrate dehydrogenase from the citric acid accumulating fungus Aspergillus niger. Biochem J 236, 549-557.

Röhr, M. \& Kubicek, C. P. (1981). Regulatory aspects of citric acid fermentation by Aspergillus niger. Proc Biocbem 16, 34-36.

Röhr, M., Stadler, P. J., Salzbrunn, W. O. J. \& Kubicek, C. P. (1979). An improved method for characterization of citrate production by conidia of Aspergillus niger. Biotechnol Lett 1, 281-286.

Röhr, M., Zehentgruber, O. \& Kubicek, C. P. (1981). Kinetics of biomass formation and citric acid production by Aspergillus niger on a pilot-plant scale. Biotecbnol Bioeng 23, 2422-2432.

Röhr, M., Kubicek, C. P. \& Kominek, J. (1992). Production of organic acids and other small molecules. In Aspergillus: Biology and Industrial Applications, pp. 91-131. Edited by J. W. Bennett \& M. A. Klich. Stoneham: Butterworth-Heinemann.

Shu, P. \& Johnson, M. J. (1948). Citric acid production by submerged fermentation with Aspergillus niger. Ind Eng Chem 40, 1202-1205.

Srere, P. A. (1980). The infrastructure of the mitochondrial matrix. Trends Biochem Sci 5, 120-121.

Veeger, C., Der Vartanian, D. V. \& Zeylemaker, W. P. (1969). Succinate dehydrogenase. Methods Enzymol 13, 81-90.

Watson, K. \& Smith, J. E. (1967). Oxidative phosphorylation and respiratory control in mitochondria from Aspergillus niger. Biochem J. 104, 332-339.

Zehentgruber, O. (1980). Kinetik, und Stoffbilanz der Citronensäuregärung. DrSc Thesis, University of Technology, Vienna, Austria.

Received 29 March 1996; revised 28 May 1996; accepted 3 June 1996. 